\title{
KONTRIBUSI KEBIASAAN BELAJAR TERHADAP PRESTASI IPA SISWA SMP
}

\section{CONTRIBUTION OF LEARNING HABITS TO ACHIEVEMENT OF JUNIOR HIGH SCHOOL STUDENTS}

\author{
Rusmia Dewi*, I Putu Artayasa dan M. Yamin \\ Program Studi Pendidikan Biologi FKIP Universitas Mataram, Mataram, Indonesia \\ *Email: rusmiadewi69@gmail.com
}

Diterima: 21 Januari 2020. Disetujui: 7 Februari 2020. Dipublikasikan: 15 Juni 2020

\begin{abstract}
Abstrak: Keberhasilan siswa dalam proses pembelajaran dapat merupakan kontribusi dari bagaimana cara siswa mempersiapkan belajarnya. Penelitian ini bertujuan untuk memaparkan kontribusi dari kebiasaan belajar terhadap hasil belajar IPA siswa. Jenis penelitian merupakan kuantitatif ex-post facto dengan subyek penelitian siswa kelas VII di SMPN 16 Mataram. Sampel penelitian diperoleh melalui teknik Random Sampling, dengan cara undian dan berdasarkan pedoman Isaac dan Michael dari jumlah populasi 113 siswa, diperoleh sampel sebanyak 84 siswa. Data penelitian berupa skor kebiasaan belajar dan hasil tes siswa. Data kebiasaan belajar diperoleh melalui penyebaran angket. Data di analisis dengan korelasi Product Moment Pearson dan dilanjutkan dengan menghitung koefisien korelasi untuk menunjukkan besarnya kontribusi kebeiasaan belajar terhadap hasil belajar. Hasil penelitian menunjukan bahwa terdapat hubungan yang positif dan signifikan antara kebiasaan belajar dan hasil belajar dan kontribusi kebiasaan belajar terhadap hasil belajar IPA siswa sebesar 40,56\%.
\end{abstract}

Kata Kunci: IPA; kebiasaan belajar; hasil belajar IPA SMP

Abstract: Student succes in the learning process can be contribution of how students prepare their learning. This study have a purpose to explain the contribution of learning habits to student science learning outcomes. This type of research is a quantitative ex-post facto with research subjects VII grade students at SMPN 16 Mataram. The research sample was obtained through at Random Sampling technique, by lottery and based on Isaac and Michael's guidelines from a population of 113, a sample of 84 students was obtained. Research data in the form of learning habits scores and students test results. Learning habits data obtained through questionnaires. Data were analyzed with Pearson Product Moment correlation and continued by calculating the correlation coefficient to show the magnitude of the contribution of learning habits to learning outcomes. The results showed that there was a positive and significant relationship between learning habits and learning outcomes and the contribution of learning habits to student science learning outcomes by $40,56 \%$.

Keywords: Natural Sciences, study habits, junior high school science learning outcomes

\section{PENDAHULUAN}

Proses belajar merupakan hal yang dialami siswa yang merupakan suatu respons terhadap segala cara pembelajaran yang diprogramkan oleh guru dan pengelolaan pembelajaran yang bertujuan untuk mencapai tujuan belajar. Belajar yang terjadi pada siswa merupakan perilaku kompleks sebagai akibat adanya interaksi antar siswa, interaksi siswa dengan guru, serta adanya tujuan tertentu. Adanya interaksi antar siswa dan siswa dengan guru berkontribusi dihasilkannya pengaruh positif terhadap hasil belajar $[1,16]$.

Hasil belajar merupakan gambaran dari hasil kegiatan pembelajaran yang telah dilakukan. Hasil belajar menunjukkan sampai sejauh mana daya serap yang dicapai siswa dalam belajar [2]. Di dalam pendidikan, siswa akan dinilai keberhasilan belajarnya melalui pemberian tes. Walaupun guru telah berupaya maksimal memfasilitasi seluruh siswa agar melakukan proses belajar yang baik di sekolah, namun antara siswa satu dengan siswa yang lain berbeda pencapaian hasil belajarnya [17].
Faktor-faktor yang mempengaruhi hasil belajar yaitu faktor internal dan eksternal $[3,18]$. Faktor internal berasal dari dua sumber yaitu kesehatan jasmani dan psikologi, sedangkan faktor eksternal bersumber dari sekolah, keluarga, dan masyarakat. Beberapa contoh faktor internal yang bersumber dari kesehatan jasmani adalah berbagai penyakit dalam tubuh, daya tahan tubuh, dan cacat tubuh, sedangkan faktor yang bersumber dari psikologi terdiri dari intelegensi, perhatian, minat, dan kebiasaan belajar.

Berdasarkan Hasil ujian Akhir Semester Ganjil tahun ajaran 2018/2019 di SMPN 6 Mataram, salah satu mata pelajaran yakni mata pelajaran IPA menunjukkan hasil yang kurang memuaskan. Rerata nilai IPA siswa khususnya kelas VII tidak sesuai dengan yang diharapkan, karena kebanyakan dari nilai mereka di bawah KKM. Berdasarkan hasil wawancara dengan guru mata pelajaran IPA kelas VII di SMPN 16 Mataram, nilai ujian akhir mata pelajaran IPA berkisar antara 15 dan 57,5 yang terpaut sangat jauh dari nilai KKM 75. 
Rendahnya hasil belajar IPA siswa disebabkan oleh beberapa faktor. Berdasarkan hasil wawancara dengan siswa kelas VII di SMPN 16 Mataram, faktor-faktor yang menyebabkan rendahnya nilai ujian IPA tersebut karena siswa kurang memahami materi-materi yang diajarkan oleh guru pada saat pembelajaran di kelas, kurang telitinya siswa dalam membaca pertanyaanpertanyaan pada soal tes, dan kebiasaan belajar siswanya yang kurang tepat. Siswa seringkali belajar hanya pada saat ujian akan berlangsung. Kebiasaan belajar ini harus menjadi fokus perhatian guru jika ingin meningkatkan hasil belajar siswanya, karena kebiasaan belajar menunjukkan perilaku belajar seseorang yang telah tertanam dalam waktu yang relatif lama yang memberikan ciri dalam aktivitas belajar yang dilakukan [4]. Kebiasaan belajar siswa berkorelasi positif yang signifikan terhadap hasil belajarnya $[5,15]$.

Upaya guru untuk membantu hasil belajar siswanya perlu didukung oleh perilaku belajar yang baik. Siswa SMP yang berada pada usia peralihan antara usia anak-anak ke dewasa masih memiliki kebiasaan belajar yang belum mantap, sehingga menimbulkan pertanyaan bagaimanakah kontribusi kebiasaan belajar siswa SMP terhadap hasil belajarnya. Dengan demikian diperlukan pengkajian kontribusi kebiasaan belajar terhadap hasil belajar IPA siswa SMP.

\section{METODE PENELITIAN}

Jenis penelitian ini adalah kuantitatif ex post facto. Populasi pada penelitian ini yaitu siswa kelas VII SMP Negeri 16 Mataram tahun ajaran 2018/2019 dengan jumlah siswa sebanyak 113 orang. Pengambilan sampel dengan teknik simple random sampling. Jumlah sampel dalam penelitian ini diambil berdasarkan pedoman yang telah dikembangkan oleh Isaac and Michael dengan taraf kesalahan 5\%. Dalam penelitian ini, sampel penelitian sebanyak 84 siswa yang diambil secara acak dengan cara undian dari populasi sebanyak 113 siswa.

Data penelitian berupa skor kebiasaan belajar dan skor tes akhir semester siswa pada pelajaran IPA. Teknik pengumpulan data menggunakan angket/kuisioner kebiasaan belajar. Kuisioner merupakan teknik pengumpulan data yang dilakukan dengan cara memberi seperangkat pertanyaan atau pernyataan tertulis kepada responden untuk dijawab [6]. Kuisioner tersebut berisi pertanyaan bagaimana kebiasaan belajar siswa yang terdiri dari indikator: (1) delay avoidan (DA), mengenai ketepatan waktu menyelesaikan tugas-tugas akademis, menghindari diri dari hal-hal yang memungkinkan tertundanya penyelesaian tugas, dan menghilangkan rangsangan yang akan mengganggu konsentrasi belajar, (2) work methods (WM) mengenai penggunaan cara belajar yang efektif dan efisien dalam mengerjakan tugas akademik dan keterampilan belajar [7].

Angket kebiasaan belajar terdiri 30 butir pertanyaan dan dari tiap butir pertanyaan siswa diminta memilih salah satu pilihan jawaban, yaitu selalu, sering, kadang-kadang, atau tidak pernah. Sementara, skor tes hasil belajar IPA siswa diperolah dari hasil tes ujian akhir semester (UAS) pada semester ganjil tahun ajaran 2018/2019. Tes yang digunakan memiliki butir tes yang valid berdasarkan uji korelasi Product Moment Pearson, serta memiliki nilai Cronbach's Alpha 0,80 dan tes yang memiliki nilai Cronbach's alpha di atas 0,60 termasuk tes yang reliabel [6].

Analisa data penelitian dilakukan korelasi Product Moment Pearson dan koefisien determinasi. Nilai koefisien determinasi ini akan memberikan informasi tentang besarnya kontribusi kebiasaan belajar terhadap hasil belajar IPA siswa. Sebelum dilakukan analisis korelasi, data kebiasaan belajar dan tes hasil belajar terlebih dahulu diuji normalitas dan homogenitasnya yang merupakan syarat dari uji statistik parametrik [8].

\section{HASIL DAN PEMBAHASAN \\ Kebiasaan Belajar}

Berdasarkan hasil analisis data dapat diketahui bahwa sebesar $11,80 \%$ dan $76,32 \%$ siswa memiliki kebiasaan belajar yang berada pada kategori tinggi dan sedang serta sisanya berkategori sangat tinggi $(2,38 \%)$, dan rendah $(9,5 \%)$, sehingga dapat dikatakan sebagian besar siswa memiliki kebiasaan belajar yang memadai pada mata pelajaran IPA. Tidak ada siswa yang memiliki kebiasaan belajar dalam kategori sangat rendah, seperti disajikan dalam Gambar 1.

Bervariasinya kebiasaan belajar siswa mulai dari kategori rendah sampai sangat tinggi tidak terlepas dari adanya perbedaan faktor-faktor yang mempengaruhi tiap siswa baik yang berasal dari dalam diri maupun lingkungan siswa. Faktor dari luar dan dalam siswa berpengaruh pada kebiasaan belajar. Faktor dari luar siswa yang sering berpengaruh adalah sikap guru. Faktor yang kurang mendukung kebiasaan belajar yang baik misalnya guru yang kurang memahami kondisi siswa, guru yang tidak adil, khususnya kepada siswa yang kurang cerdas. Keadaan ekonomi orang tua, siswa yang sering alfa atau tidak masuk sekolah dikarenakan tidak adanya uang transport untuk kesekolah yang dikarenakan sekolah memiliki jarak yang jauh dari rumah, atau siswa tidak dapat mengerjakan tugas karena tidak adanya buku LKS dan kesulitan belajar dirumah karena tidak ada perlengkapan untuk belajar seperti buku paket. Selanjutnya faktor luar yang lainnya yaitu kasih sayang dan perhatian dari orang tua. Siswa malas belajar pada umumnya dikarenakan kurang kasih sayang dan perhatian dari orang tua. 


\section{Hasil Belajar}

Sebagian besar hasil belajar IPA siswa kelas VII berada pada kategori sedang dan rendah yaitu masing-masing $53,68 \%$ dan $21,42 \%$. Sementara itu, kategori sangat tinggi, tinggi, dan sangat rendah yaitu masing-masing sebesar $1,1 \%, 15,47 \%$, dan 8,33\% (Gambar 2). Adanya hasil belajar pada kategori tinggi ini dikarenakan siswa memiliki kebiasaan belajar yang baik.

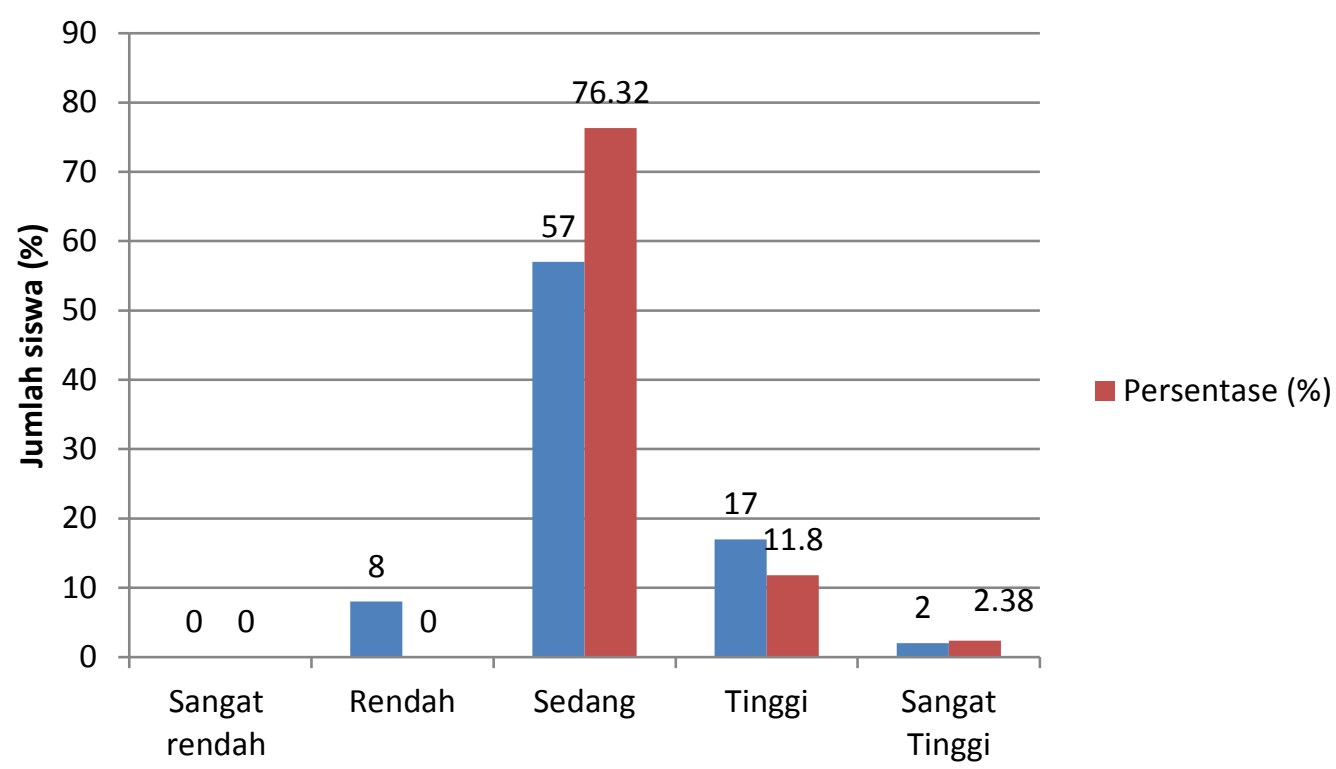

Gambar 1.Jumlah Siswa pada Lima Kategori Kebiasaan Belajar

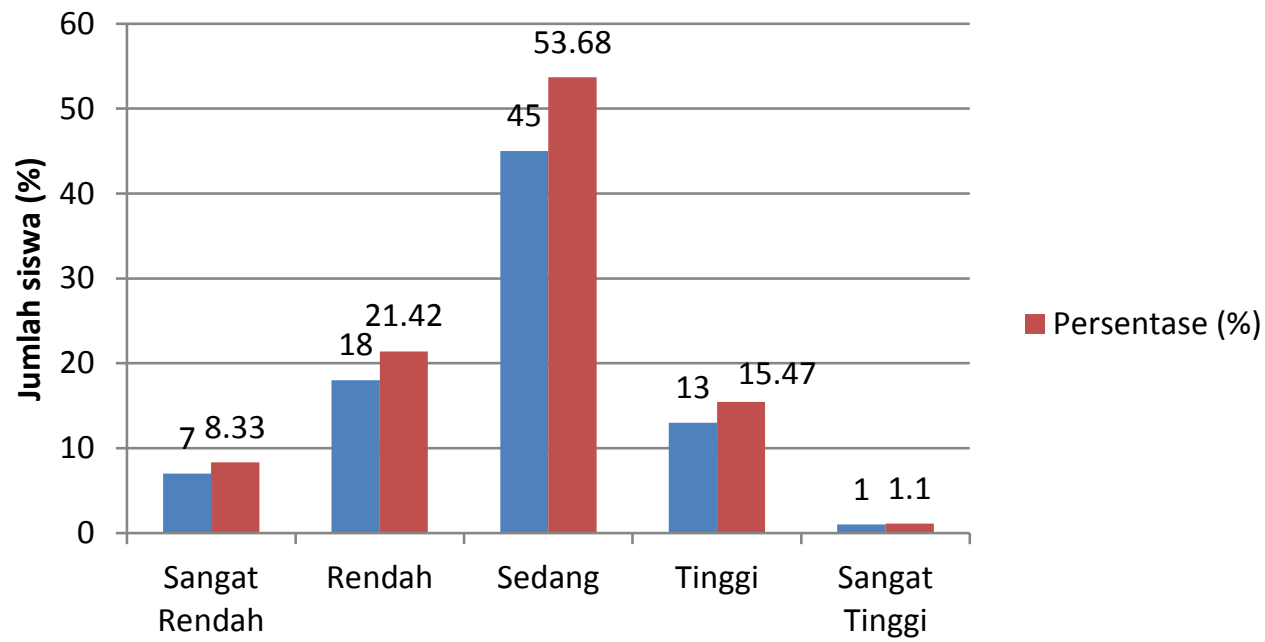

Gambar 2. Jumlah Siswa pada Lima Kategori Hasil Belajar

Adanya hasil belajar siswa pada kategori sangat rendah dengan persentase $8,33 \%$ menunjukkan bahwa ada beberapa siswa walaupun tidak besar yang mengalami kesulitan belajar yang tinggi. Kesulitan belajar tidak selalu disebabkan karena rendahnya IQ, artinya tingginya IQ tidak menjamin siswa tersebut memiliki hasil belajar yang sangat baik. Salah satu faktornya adalah kebiasaan belajar yang kurang baik. Kesulitan belajar tidak selalu disebabkan karena faktor intelegensi yang rendah (kelainan mental), akan tetapi dapat juga disebabkan oleh faktor-faktor di luar intelegensi.[9]

\section{Hubungan Kebiasaan Belajar dengan Hasil} Belajar

Hasil kebiasaan belajar dan hasil belajar siswa jika dihubungkan terdapat sedikit perbedaan. Pada nilai persentase kebiasaan belajar siswa tidak ada siswa yang termasuk dalam kategori sangat rendah, sedangkan pada nilai hasil belajar, masih terdapat siswa pada kategori sangat rendah. Hal ini 
disebabkan karena masih ada siswa yang dalam kegiatan sehari-hari ditemukan kebiasaan belajar yang kurang baik. Kebiasaan belajar tersebut diantaranya belajar yang tidak teratur, belajar hanya pada saat ujian akhir semester, berkelakuan buruk, dan sampai tidak masuk sekolah.

Hubungan antara kebiasaan belajar dengan hasil belajar memiliki nilai koefisien korelasi sebesar 0,64. Hal ini menunjukkan bahwa terdapat hubungan yang positif dan signifikan antara kebiasaan belajar dan hasil belajar. Apabila kebiasaan belajar meningkat maka hasil belajar juga akan meningkat. Hasil uji determinasi menunjukkan nilai sebesar 0,4056 atau sebesar $40,56 \%$. Hal ini berarti nilai yang terjadi pada variabel hasil belajar IPA 40,56\% dapat dijelaskan melalui nilai yang terjadi pada variabel kebiasaan belajar atau berhubungan dengan kebiasaan belajar siswa dan59,44\% dijelaskan oleh faktor lain.

Adanya kontribusi yang cukup besar dari kebiasaan belajar tersebut mengindikasikan bahwa baik orang tua siswa maupun guru harus selalu memantau kebiasaan belajar siswanya. Pemantauan itu dapat dilakukan baik dengan diskusi dan pemberian tugas-tugas yang membantu kebiasaan belajar yang baik. Pendidikan pertama kali diperoleh siswa di rumah sehingga orang tua sangat perlu mengawasi serta membimbing siswa untuk belajar[10]. Hal ini sependapat dengan orang tua perlu membimbing dan mengingatkan siswa untuk belajar serta memberikan pemahaman tentang kapan saat untuk siswa bermain dan kapan saat untuk belajar [11]. Penggunaan waktu belajar yang efisien dapat meningkatkan keberhasilan belajar seseorang [12]. Selain dari bimbingan orang tua, peran guru juga sangat penting dalm pembentukan kebisaan belajar siswa. Memberikan tips agar siswa dapat belajar dengan efektif [13]. Salah satunya yaitu dengan pemberian tugas. Soal ataupun tugas tersebut dapat siswa pelajari dan baca kembali agar dapat paham secara keseluruhan. Hal tersebut bertujuan apabila siswa menemukan soal yang hampir sama dengan soal yang dianalisis sebelumnya, siswa dapat mengerjakannya dengan mudah. Pendapat yang hampir sama diungkapkan oleh Crow dan Crow yang menuliskan cara untuk membiasakan diri belajar yang efisein adalah dengan adanya tugas yang jelas [14].

Meskipun siswa telah memenuhi kebiasaan belajarnya dengan kontribusinya sebesar $40,56 \%$, namun faktor-faktor lain juga mempegaruhi hasil belajarnya. Faktor-faktor lain tersebut antara lain minat, perhatian orang tua, intelegensi, sekolah, dan bakat siswa. Jika dilihat dari banyaknya faktor lain yang berhubungan dengan hasil belajar, yaitu sebesar 59,44\% sehingga faktor lain tersebut juga harus menjadi perhatian yang serius bagi guru untuk menetukan strategi pembelajaran agar dapat meningkatkan hasil belajar IPA siswa.

\section{KESIMPULAN}

Berdasarkan hasil penelitian dan pembahasan, dapat disimpulkan bahwa kebiasaan belajar siswa sebagian besar termasuk dalam kategori sedang dengan persentasae sebesar 76,32\%. Hasil belajar siswa sebagian besar termasuk dalam kategori sedang dengan persentase 53,68\%. Terdapat hubungan yang positif dan signifikan antara kebiasaan belajar dan hasil belajar siswa dengan nilai $\mathrm{r}=0,6369$, sementara kontribusi kebiasaan belajar terhadap hasil belajar sebesar $40,56 \%$. $\left(r^{2}=\right.$ 0,4056).

\section{DAFTAR PUSTAKA}

[1] Retnowati, F. (2017). Hubungan Kebiasaan Belajar Dan Lingkungan Sekolah Terhadap Hasil Belajar Ips Kelas V. Joyful Learning Journal, 6(3), 197-205.

[2] Auron, d. (2006). Hubungan Kebiasaan Belajar Matematika Siswa dengan Hasil Belajar Di SMA Negeri 2 Ciputat. Skripsi Jurusan Pendidikan Matematika Fakultaas Ilmu Tarbiyah Dan Keguruan. Jakarta: Universitas Islam Negeri.

[3] Slameto. (2010). Belajar dan Faktor-Faktor yang Mempengaruhinya. Jakarta: Rineka Cipta.

[4] Aunurrahman. (2010). Prosedur Penelitian Suatu Pendekatan Praktik. Jakarta: Rineka Cipta.

[5] Rahayu, M. M. (2015). Pengaruh Kebiasaan Belajar terhadap Hasil Belajar Matematika. Journal of Elementary Education, 4(1), 39-45.

[6] Sugiyono. (2018). Metode Penelitian Kuantitatif, Kualitatif, dan $R \& D$. Bandung: Alfabeta.

[7] Djaali. (2014). Psikologi Pendidikan. Jakarta: Bumi Aksara.

[8] Richie. (2019). Mobile Statistik, Research and Consulting, diaskes dari http//:www.mobileestatic.com.

[9] Dalyono, M. (2010). Psikologi Pendidikan. Jakarta: Rineka Cipta.

[10] Hidayati, A. K. (2016). Hubungan Kebiasaan Belajar dengan Hasil Belajar Siswa Kelas IV SD Se-Gugus II Piyungan. BASIC EDUCATION, 5(30), 2-895.

[11] Ariantoro, T. R. (2016). Dampak Game Online Terhadap Prestasi Belajar Pelajar. JUTIM (Jurnal Teknik Informatika Musirawas), 1(1).

[12] Mulyatiningsih, R. (2004). Bimbingan PribadiSosial, Belajar, dan Karier. Jakarta: Gramedia

[13] Suparno, A.Suhaenah. (2001). Membangun Kompetensi Belajar. Jakarta: Direktorat Jendral Pendidikan Tinggi.

[14] Purwanto, N. (2007). Psikologi Pendidikan. Bandung: PT. Remaja Rosdakarya.

[15] Sakaroni. (2016). Hubungan Kebiasaan Belajar dengan Hasil Belajar Biologi Siswa 
SMAN 1 Narmada Tahun Ajaran 2015/2016. Skripsi Jurusan Pendidikan Biologi. Fakultas Keguruan dan Ilmu Pendidikan: Universitas Mataram.

[16] Hadiprayitno, G., \& Khair, B. N. (2018). Pemantapan Kemampuan Mengajar Berbasis Lesson Study Di Program Magister Pendidikan Ipa Universitas Mataram. Jurnal Pijar Mipa, 13(1), 68-75.

[17] Wulaningsih, W. (2012). Pengaruh Kebiasaan Belajar Dan Lingkungan Sekolah Terhadap Prestasi Belajar Pada Kompetensi Mengelola Kartu Aktiva Tetap Siswa Kelas XI Program
Keahlian Akuntansi SMK Muhammadiyah Cawas Tahun Ajaran 2011/2012. Kajian Pendidikan Akuntansi Indonesia, 1(3).

[18] Yulianti, R., Muntari, M., \& Haris, M. (2015). Pengaruh model pembelajaran kooperatif tipe two stay two stray (tsts) dengan pendekatan brain-based learning terhadap hasil belajar kimia materi pokok struktur atom dan sistem periodik unsur pada siswa kelas $\mathrm{x}$ sman 1 kediri. Jurnal pijar MIPA, 10(1). 